\title{
Pengaruh Kombinasi Biochar Sekam Padi dan Pupuk Organik Berbasis Mikroba Terhadap Pertumbuhan dan Produksi Sayuran
}

\author{
The effect of husk charcoal biochar and microbial-based organic fertilizer on the growth vegetables
}

\author{
Siti Suharyatun ${ }^{1 *}$, Warji1 ${ }^{1}$ Agus Haryanto', Khoiril Anam²
}

\begin{abstract}
1Jurusan Teknik Pertanian, Fakultas Pertanian, Universitas Lampung, Jl. Sumantri Brojonegoro 1, Bandar Lampung
2Mahasiswa Jurusan Teknik Pertanian, Fakultas Pertanian, Universitas Lampung, Jl. Sumantri Brojonegoro, 1 Bandar Lampung

*E-mail: sitisuharyatun149@gmail.com
\end{abstract}

Diterima: 10 Februari 2021; Disetujui: 9 Agustus 2021

\begin{abstract}
ABSTRAK
Pemanfaatan biochar sekam padi merupakan salah satu upaya pengelolaan limbah pertanian untuk memperbaiki karakteristik dan kesuburan tanah. Penelitian penggunaan biochar sekam padi sebagai bahan pembenah tanah sudah banyak dilakukan, tetapi penggunaan biochar sekam padi yang dikombinasikan dengan pupuk organik berbasis mikroba belum banyak dilakukan. Biochar sekam padi dapat menyediakan habitat bagi mikroba tanah, kombinasi biochar sekam padi dengan pupuk organik berbasis mikroba diharapkan dapat memperbaiki karakteristik fisik dan kimia tanah, serta meningkatkan kesuburan tanah sekaligus mengurangi penggunaan pupuk anorganik. Penelitian ini bertujuan untuk mengetahui pengaruh kombinasi penggunaan biochar dan pupuk organik berbasis mikroba terhadap pertumbuhan dan hasil produksi sayuran. Penelitian ini menggunakan 4 perlakuan, yaitu (1) tanpa biochar tanpa pupuk, (2) menggunakan pupuk organik berbasis mikroba, (3) menggunakan biochar dan (4) menggunakan biochar dan pupuk organik berbasis mikroba. Parameter yang diamati dalam penelitian adalah pertumbuhan dan produksi tanaman, serta karakteristik fisik dan kima tanah sebagai pendukung. Pengukuran parameter pertumbuhan tanaman dilakukan secara periodik selama pertumbuhan tanaman, produksi tanaman diukur setelah panen. Hasil penelitian menyatakan bahwa pemberian pupuk organik berbasis mikroba atau biochar pada tanah subsoil berpengaruh meningkatkan tinggi tanaman, jumlah daun, luas kanopi dan total brangkasan tanaman sawi. Kombinasi pupuk berbasis mikroba dan biochar arang sekam menghasilkan rata-rata tinggi tanaman dan total brangkasan lebih besar dibanding pemberian pupuk organik berbasis mikroba saja atau biochar saja.
\end{abstract}

Kata kunci: arang sekam; budidaya sayuran; limbah pertanian; pupuk hayati

\section{ABSTRACT}

The use of biochar is one of the agricultural waste management efforts to improve soil characteristics and fertility. Researchers have carried out some researches on the use of biochar as a soil amendment, but the use of bio char in combination with microbial-based organic fertilizers has not been widely used. Biochar can provide a habitat for soil microbes. The combination of bio char with microbial-based organic fertilizers can improve the physical and chemical characteristics of the soil, and increase soil fertility while reducing the use of inorganic fertilizers. This study aims to determine the effect of the combined use of biochar and microbial-based organic fertilizers on soil characteristics, growth and yield of vegetables. This study used 4 treatments, namely (1) without biochar without fertilizer, (2) using microbial-based organic fertilizers, (3) using biochar and (4) using biochar and microbial-based organic fertilizers. The parameters observed in the study were plant growth and production. Plant growth parameters were measured periodically during plant growth, crop production was measured after harvest. The results showed that the application of microbial-based organic fertilizers, or biochar, to subsoil soils had the effect of increasing height, leaf number, canopy area and total the whole plant of the mustard greens. The combination of microbial-based fertilizers and biochar produced plant height and a greater total the whole plant than only microbial-based organic fertilizers or only biochar.

Keywords: husk charcoal; vegetable cultivation; agricultural waste; biological fertilizers

\section{PENDAHULUAN}

Biochar atau biomassa charcoal merupakan arang kayu berpori (porous) yang dapat diperoleh dari hasil konversi kayu atau bahan organik lain seperti limbah organik (biomas pertanian) melalui pembakaran tidak sempurna atau suplai oksigen terbatas (pyrolysis). Biochar juga didefinisikan sebagai bahan organik padat yang diproduksi melalui pemrosesan termo-kimia biomassa tanpa adanya atau di bawah lingkungan oksigen tereduksi yang terbatas (Gonzaga et al., 2017). 'Biochar' adalah arang bahan organik yang sengaja diterapkan pada tanah untuk meningkatkan sifat-sifat tanah. Ini membedakan biochar dari arang yang digunakan sebagai bahan bakar, sebagai filter, atau sebagai reduktor dalam pembuatan besi (Lehmann \& Joseph, 2009). Biochar adalah produk kaya karbon dengan komposisi yang sangat stabil dan tidak mengalami degradasi. Komponen organik biochar memiliki kandungan karbon yang tinggi dan komponen anorganik mengandung mineral, seperti $\mathrm{Ca}, \mathrm{Mg}$, $\mathrm{K}$, dan karbonat anorganik (ion karbonat); bergantung pada jenis bahan bakunya (Rajaphaksa et al., 2016).

Salah satu biochar yang digunakan sebagai bahan pembenah tanah adalah biochar dari arang sekam padi. Pemberian perlakuan biochar sekam padi pada tanah Ultisol 
dengan jenis tanah Typic Kanhapludult dengan dosis tinggi memberikan pengaruh nyata terhadap sifat fisik tanah, seperti menurunkan berat isi dan berat jenis tanah, serta meningkatkan ruang pori total (RPT) dan pori air tersedia tanah (PAT). Pemberian biochar sekam padi dosis tinggi ini juga dapat meningkatkan kandungan $\mathrm{C}$-organik tanah seiring penambahan perlakuan dosis biochar sekam padi. (Widyantika \& Prijono, 2019).

Proses termo-kimia untuk memproduksi biochar dilakukan pada kisaran suhu dari $250^{\circ}-700^{\circ} \mathrm{C}$. Meta-analisis menggunakan dua puluh tujuh artikel mengungkapkan bahwa suhu pirolisis merupakan faktor yang berkontribusi besar terhadap tujuan penggunaan biochar (Baidoo et al., 2016). Teknologi proses mempengaruhi sifat utama biochar seperti komposisi unsur dan abu, luas permukaan spesifik, $\mathrm{pH}$. Tabel 1 menunjukkan teknologi pembuatan biochar dan sifat produknya.

Tabel 1. Teknologi pembuatan biochar dan karakteristiknya (Kumarathilaka et al., 2016).

\begin{tabular}{lccc}
\hline Technology & $\begin{array}{c}\text { Temperature } \\
\left({ }^{\circ} \mathrm{C}\right)\end{array}$ & $\begin{array}{c}\text { Biochar } \\
\text { Products } \\
(\%)\end{array}$ & $\begin{array}{c}\text { Carbon in } \\
\text { Biochar } \\
(\%)\end{array}$ \\
\hline $\begin{array}{l}\text { Slow } \\
\text { pyrolysis }\end{array}$ & $100-1000$ & 35 & $\sim 50-95$ \\
\hline $\begin{array}{l}\text { Intermediate } \\
\text { pyrolysis }\end{array}$ & $\sim 500$ & 25 & $66-74$ \\
\hline $\begin{array}{l}\text { Fast } \\
\text { pyrolysis }\end{array}$ & $300-1000$ & $\sim 12-25$ & $\sim 64-90$ \\
\hline Gasification & $\sim 900$ & 10 & 65 \\
\hline
\end{tabular}

Karakteristik umum biochar dibandingkan dengan arang pada umumnya adalah terutama terdiri dari karbon aromatik yang stabil, dan, dibandingkan dengan karbon dalam bahan baku pirolisis, tidak dapat dengan mudah dikembalikan ke atmosfer sebagai $\mathrm{CO}_{2}$ (Sandhu et al., 2017). Hal ini juga terjadi di bawah kondisi lingkungan dan biologis yang menguntungkan, seperti yang mungkin ada di tanah. Sifatsifat penting biochar adalah luas permukaan yang tinggi dengan banyak gugus fungsi, kandungan nutrisi yang tinggi, dan pupuk slow-release (Ding et al., 2016). Biochar juga memiliki sifat fisik yang membantu dalam retensi nutrisi di tanah. Penggunaan biochar tidak diragukan lagi memiliki dampak yang signifikan tidak hanya pada nutrisi tanah tetapi juga pada komunitas organisme tanah dan fungsinya.

Aplikasi biochar ke lahan pertanian (lahan kering dan basah) dapat meningkatkan kemampuan tanah menyimpan air dan hara, memperbaiki kegemburan tanah, mengurangi penguapan air dari tanah dan menekan perkembangan penyakit tanaman tertentu serta menciptakan habitat yang baik untuk mikroorganisme simbiotik (Nurida et al., 2015).

Biochar bukan merupakan pupuk organik karena tidak dapat menambah unsur hara, tetapi kapasitas tukar kation (KTK) pada biochar tinggi sehingga mampu mengikat kationkation tanah yang dapat dimanfaatkan untuk pertumbuhan tanaman(Elviwirda, 2020). Penyediaan unsur hara tanah bagi tanaman dapat dilakukan dengan pemupukan, baik pupuk organik maupun anorganik. Penggunaan biochar sebagai pembenah tanah bersama pupuk organik dan anorganik dapat meningkatkan produktivitas serta retensi dan ketersediaan hara bagi tanaman(Gani \& Anischan, 2009).

Pupuk organik merupakan jenis bahan organik yang berasal dari tanaman dan hewan dan dapat dirombak menjadi hara tersedia bagi tanaman. Pupuk organik berbasis mikroba atau pupuk hayati merupakan semua kelompok fungsional mikroba tanah yang dapat berfungsi sebagai penyedia unsur hara dalam tanah sehingga dapat tersedia bagi tanaman (Simanungkalit et al., 2006). Kelebihan dari pupuk hayati diantaranya adalah tidak menimbulkan residu pada tanah serta penggunaan pupuk relatif ekonomis karena jumlah yang diaplikasikan semakin lama semakin menurun. $\mathrm{Hal}$ ini disebabkan adanya mikroba dapat membantu menjaga ketersediaan unsur hara pada tanah. Mikroba akan berkembang dengan baik jika memperoleh habitat yang sesuai. Biochar menyediakan media tumbuh yang baik bagi berbagai mikroba (Rondon et al., 2007).

Mengkombinasikan biochar dengan pupuk organik berbasis mikroba diharapkan dapat memperbaiki sifat fisik tanah dan dapat pengurangi penggunaan pupuk anorganik dengan tetap mempertahankan produktivitas tanaman. Biochar diharapkan dapat menjadi habitat yang baik mikroorganisme yang ada di dalam pupuk. Penelitian ini bertujuan untuk mengetahui pengaruh penggunaan biochar sekam padi yang dikombinasikan dengan pupuk organik berbasis mikroba terhadap pertumbuhan dan produksi sayuran.

\section{METODOLOGI}

Penelitian dilaksanakan bulan Februari sampai Mei 2020 Lab. Rekayasa Sumber Daya Air dan Pengelolaan Limbah, Jurusan Teknik Pertanian, Universitas Lampung.

Alat yang digunakan dalam penelitian adalah polybag $20 \times 30 \mathrm{~cm}$, ayakan, timbangan, cangkul, alat ukur (meter), gembor. Bahan yang digunakan adalah tanah yang diambil dari lapisan subsoil (kedalaman $40-80 \mathrm{~cm}$ ), rock wool, benih sawi, pupuk organik berbasis mikroba, dan biochar dari sekam padi.

Tanah yang digunakan sebanyak $2,5 \mathrm{~kg}$ per polybag. Pupuk digunakan dalam penelitian adalah pupuk Bio-Galy Organik berbentuk cair, yang merupakan pupuk organik berbasis mikroba penambat $\mathrm{N}$, pelarut $\mathrm{P}$ dan pengurai $\mathrm{K}$. Pupuk diberikan dengan dosis 32,3 liter per hektar $(6 \mathrm{ml}$ per tanaman). Sebelum digunakan Pupuk di encerkan dengan air. Pupuk diberikan secara bertahap, yaitu sebelum bibit dipindahkan ke polybag, 1 dan 3 minggu setelah bibit dipindahkan ke polybag. Biochar arang sekam padi diberikan dengan 180 gram per polybag.

Rancangan percobaan yang digunakan dalam penelitian adalah rancangan acak lengkap (RAL) dengan 4 perlakuan dan 7 ulangan. Perlakuan dalam penelitian disajikan pada Tabel 2.

Tabel 2. Perlakuan dalam penelitian

\begin{tabular}{cl}
\hline Kode perlakuan & Deskripsi \\
\hline P0 & $\begin{array}{l}\text { Kontrol (tanpa biochar dan pupuk } \\
\text { organik berbasis mikroba) }\end{array}$ \\
\hline P1 & Pupuk organik berbasis mikroba \\
\hline P2 & Biochar \\
\hline P3 & $\begin{array}{l}\text { Biochar + pupuk organik berbasis } \\
\text { mikroba }\end{array}$ \\
\hline
\end{tabular}

Penelitian dibagi ke dalam 3 tahapan, yaitu:

1. Pembuatan biochar arang sekam

2. Persiapan media tanam

3. Penanaman

Penanaman sawi dilakukan dengan memindah bibit tanaman yang telah disemai (umur 14 hari) kedalam polybag.

Parameter yang diamati dalam penelitian adalah:

1. Sifat fisik tanah (tekstur) dan kimia tanah (Nitrogen $(\mathrm{N})$, Fosfor (P), C-organik, KTK, dan pH tanah), diukur sebelum penelitian untuk mengetahui karakteristik fisik dan kimia tanah yang digunakan.

2. Parameter pertumbuhan tanaman, diamati secara periodik setelah tanaman dipindahkan ke dalam polybag: 
tinggi tanaman (cm), jumlah daun (helai) dan luas kanopi daun $\left(\mathrm{cm}^{2}\right)$.

3. Hasil panen: berat brangkasan total (gram).

Data yang diperoleh disajikan dalam bentuk grafik dan dianalisis ragam (anova) pada taraf uji $5 \%$. Apabila terdapat perbedaan antara perlakuan, dilanjutkan dengan uji BNT.

\section{HASIL DAN PEMBAHASAN}

Hasil uji sifat fisik tanah menunjukkan tanah subsoil yang digunakan penelitian ini bertekstur liat dengan komposisi pasir $26,71 \%$, debu $21,67 \%$ dan liat $51,67 \%$. Hasil uji sifat kimia, tanah memiliki pH 5,26, C-organik 0,29\%, Nitrogen 0,04\%, P-tersedia 0,85 ppm dan K 0,78 (me/100 g). Hal menunjukkan bahwa tanah memiliki $\mathrm{pH}$ sedang, C-organik sangat rendah, nitrogen sangat rendah, $\mathrm{P}$-tersedia sangat rendah, dan kandungan $\mathrm{K}$ tergolong sedang.

\section{Tinggi tanaman}

Hasil pengukuran tinggi tanaman disajikan dalam grafik hubungan tinggi tanaman dengan waktu pada Gambar 1. Grafik pada Gambar 1 menunjukkan bahwa tinggi tanaman pada tanah yang diberi pupuk organik berbasis mikroba (P1), lebih baik dibandingkan kontrol (P0). Tinggi tanaman pada tanah yang diberi biochar arang sekam (P2) lebih baik dibandingkan tanah yang diberi pupuk organik berbasis mikroba (P2). Tinggi tanaman pada tanah yang diberi pupuk organik berbasis mikro dan biochar arang sekam (P3) menghasilkan pertumbuhan yang lebih baik dibanding pemberian arang sekam saja. Hal ini sesuai dengan hasil penelitian (Topani et al., 2017) yang menyatakan peanambahan abu ketel pabrik tebu dan kompos menghasilkan rerata tinggi tanaman tebu paling tinggi pada umur 3 dan 6 bulan setelah tanam. Hasil penelitian lainnya (Handoko et al., 2017) juga menunjukkan pengaruh kombinasi pemberian arang tempurung kelapa dan abu sekam padi terhadap peningkatan tinggi tanaman tebu.

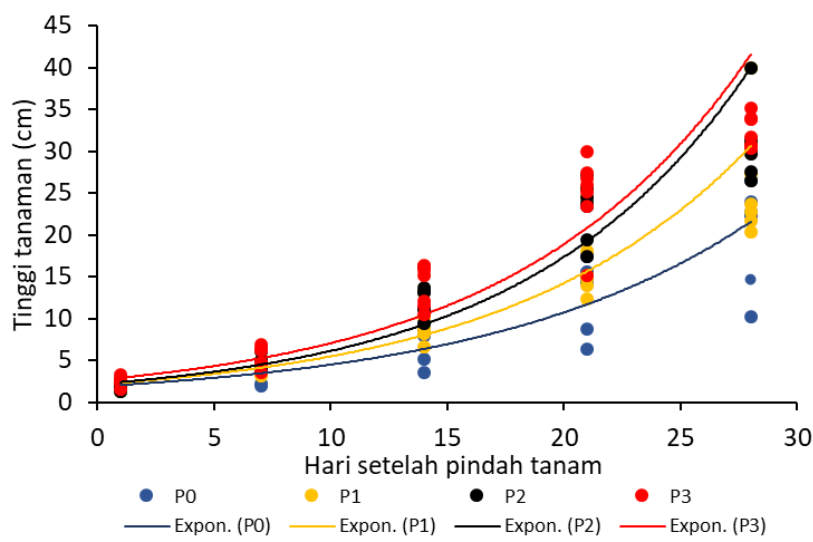

Gambar 1. Grafik hubungan tinggi tanaman dengan waktu

Hasil uji anova pada umur 28 hari setelah pindah tanam menunjukkan bahwa perlakuan yang diberikan berpengaruh signifikan terhadap tinggi tanaman sebagaimana disajikan pada Tabel 3. Selanjutnya, hasil uji BNT (Tabel 4), menyatakan bahwa rata-rata tinggi tanaman sawi pada tanah yang diberi pupuk organik berbasis mikroba (P1) lebih besar dibanding kontrol (P0). Pengaruh pemberian pupuk saja (P1) tidak berbeda nyata dengan pemberian biochar saja (P2). Pemberian pupuk organik berbasis mikroba yang dikombinasikan dengan biochar (P3) memberikan pengaruh yang lebih baik dibandingkan pemberian biochar saja (P2) atau pupuk organik berbasis mikroba saja (P1).

Pupuk organik berbasis mikroba merupakan produk biologi-aktif yang terdiri dari mikroba yang berfungsi meningkatkan kesuburan dan kesehatan tanah. Peningkatan kesuburan dan kesehatan tanah akan berpengaruh terhadap pertumbuhan tinggi tanaman dimana tinggi tanaman yang diberi pupuk organik berbasis mikroba mengalami pertumbuhan yang lebih optimal dibandingkan kontrol.

Pemberian biochar berpengaruh terhadap peningkatan tinggi tanaman. Hal ini diduga karena biochar mampu mengikat kation-kation di dalam tanah sehingga dapat dimanfaatkan oleh tanaman. Hasil Penelitian (Nisa, 2010) menyatakan bahwa pemberian biochar jauh lebih efektif meningkatkan retensi hara bagi tanaman dibandingkan kompos dan pupuk kandang.

Kombinasi biochar dan pupuk organik berbasis mikroba berpengaruh positif terhadap peningkatan tinggi tanaman. Hal ini sesuai dengan pernyataan (Gani \& Anischan, 2009) bahwa penggunaan biochar bersama pupuk organik dan anorganik dapat meningkatkan produktivitas serta retensi dan ketersediaan hara bagi tanaman.

Tabel 3. Hasil uji anova tinggi tanaman pada umur 28 hari setelah pindah tanam pada taraf $5 \%$

\begin{tabular}{lrrrcrc}
\hline $\begin{array}{l}\text { Source of } \\
\text { Variation }\end{array}$ & SS & Df & MS & $F$ & $\begin{array}{c}P- \\
\text { value }\end{array}$ & $\begin{array}{c}F \\
\text { crit }\end{array}$ \\
\hline Perlakuan & 598,31 & 3 & 199,44 & $7,73^{*}$ & 0,0009 & 3,01 \\
Galat & 619,34 & 24 & 25,81 & & & \\
Total & 1217,66 & 27 & & & & \\
\hline
\end{tabular}

Tabel 4. Hasil uji BNT tinggi tanaman pada umur 28 hari setelah pindah tanam, pada taraf $5 \%$

\begin{tabular}{cc}
\hline Perlakuan & Rata-rata \\
\hline P0 & $20,41^{\mathrm{a}}$ \\
P1 & $26,67^{\mathrm{b}}$ \\
P2 & $30,90^{\mathrm{b}}$ \\
P3 & $32,30^{\mathrm{c}}$ \\
\hline
\end{tabular}

\section{Jumlah daun}

Pertumbuhan jumlah daun tanaman sawi disajikan dalam grafik hubungan jumlah daun dengan umur tanaman setelah pindah tanam pada Gambar 2.

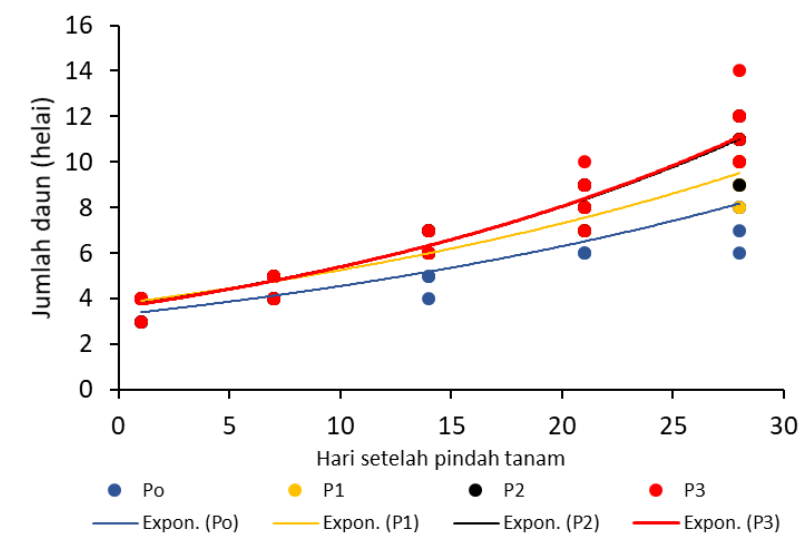

Gambar 2. Grafik hubungan jumlah daun dengan waktu

Grafik pada Gambar 2 terlihat jumlah daun tanaman sawi pada P1, P2 dan P3 lebih banyak dibanding P0. Jumlah daun pada P2 dan P3 lebih baik dari P1. Jumlah daun pada P2 dan P3 tidak berbeda; terlihat dari grafik yang berhimpit. Hal menunjukkan bahwa pemberian pupuk organik berbasis 
mikroba dapat meningkatkan pertumbuhan jumlah daun sawi. Pemberian biochar meningkatkan pertumbuhan jumlah daun lebih baik dibanding pemberian pupuk organik berbasis mikroba. Kombinasi biochar dan pupuk organik berbasis mikroba tidak memberikan efek jumlah daun yang berbeda nyata dengan perlakuan pemberian biochar saja.

Hasil uji anova pada umur 28 hari setelah pindah tanam menunjukkan bahwa perlakuan yang diberikan berpengaruh terhadap jumlah daun (Tabel 5). Pengaruh perlakuan dapat dilihat pada hasil uji BNT pada Tabel 6 .

Hasil uji BNT menunjukkan bahwa pemberian pupuk organik berbasis mikroba (P1) dapat meningkatkan jumlah daun dibanding kontrol (P0). Pemberian biochar arang sekam (P2) dapat meningkatkan jumlah daun lebih banyak dibanding pemberian pupuk organik berbasis mikroba (P1). Kombinasi pemberian pupuk organik berbasis mikroba dan biochar (P3) memberikan pengaruh yang sama dengan pemberian biochar saja (P2).

Peningkatan jumlah daun pada tanaman yang diberikan pupuk organik berbasis mikroba menunjukkan bahwa pemberian pupuk organik berbasis mikroba dapat meningkatkan kesuburan dan kesehatan tanah yang berpengaruh terhadap pertumbuhan tanaman yang dapat dilihat meningkatnya tinggi tanaman dan jumlah daun.

Pemberian biochar yang dapat meningkatkan jumlah daun dibanding dengan kontrol, menunjukkan bahwa biochar dapat meningkatkan retensi hara tanaman sehingga berpengaruh positif terhadap pertumbuhan tanaman berupa meningkatnya tinggi tanaman dan jumlah daun

Tabel 5. Hasil uji anova jumlah daun pada umur 28 hari setelah pindah tanam pada taraf $5 \%$

\begin{tabular}{lcrrcrc}
\hline $\begin{array}{c}\text { Source of } \\
\text { Variation }\end{array}$ & $S S$ & $D f$ & $M S$ & $F$ & P-value & $\begin{array}{c}F \\
\text { crit }\end{array}$ \\
\hline Perlakuan & 42,96 & 3 & 14,32 & $12,40^{*}$ & 0,00004 & 3,01 \\
Galat & 27,71 & 24 & 1,15 & & & \\
Total & 70,68 & 27 & & & & \\
\hline
\end{tabular}

Tabel 6. Hasil uji BNT jumlah daun pada taraf $5 \%$

\begin{tabular}{cc}
\hline Perlakuan & Rata-rata \\
\hline P0 & $8,00^{\mathrm{a}}$ \\
P1 & $9,57^{\mathrm{b}}$ \\
P2 & $11,00^{\mathrm{c}}$ \\
P3 & $11,00^{\mathrm{c}}$ \\
\hline
\end{tabular}

\section{Luas kanopi daun}

Hasil pengukuran luas kanopi daun sawi disajikan dalam bentuk grafik pada Gambar 3. Grafik pada Gambar 3 menunjukkan bahwa luas kanopi P1 lebih besar dari P0, luas kanopi daun P2 lebih besar dibanding P1, dan luas kanopi daun P3 lebih besar dari P2. Hal ini menunjukkan bahwa pemberian pupuk organik berbasis mikroba atau biochar arang sekam berpengaruh terhadap luas kanopi daun tanaman sawi.

Hasil uji anova pada Tabel 7 juga menunjukkan bahwa perlakuan yang diberikan berpengaruh nyata terhadap luas kanopi daun. Hasil uji BNT menunjukkan bahwa pemberian pupuk organik berbasis mikroba (P1) tidak berpengaruh terhadap luas kanopi daun dibanding kontrol (P0). Pemberian biochar arang sekam (P2) serta kombinasi pemberian pupuk organik berbasis mikroba dan biochar (P3) dapat meningkatkan luas kanopi daun. Penambahan pupuk organik berbasis mikroba pada tanah yang diberi biochar sekam padi (P3) memberikan pengaruh yang tidak berbeda nyata dengan pemberian biochar sekam padi saja (P2) terhadap luas kanopi daun. Luas kanopi mengalami peningkatan seiring dengan peningkatan jumlah daun pada tanaman sawi.

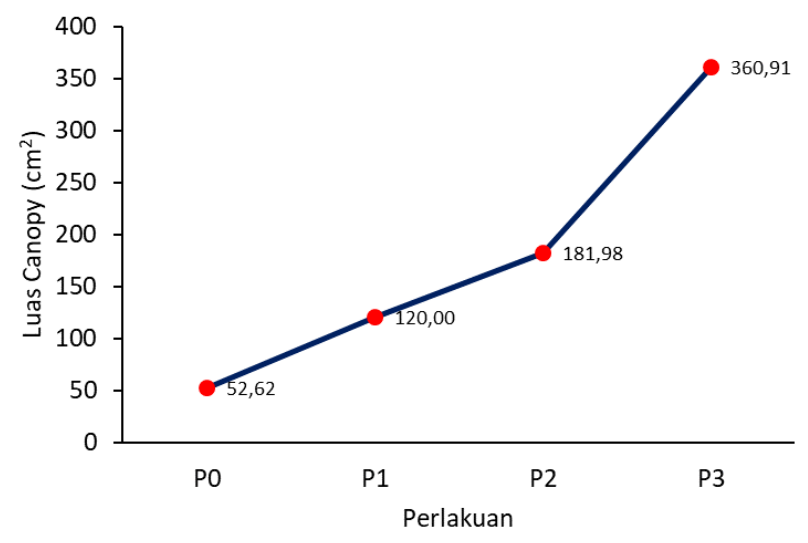

Gambar 3. Grafik luas kanopi daun

Tabel 7. Hasil uji anova luas kanopi daun pada taraf $5 \%$

\begin{tabular}{lcrrrrr}
\hline $\begin{array}{c}\text { Source of } \\
\text { Variation }\end{array}$ & $S S$ & $d f$ & \multicolumn{1}{c}{ MS } & $F$ & P-value & $\begin{array}{c}F \\
\text { crit }\end{array}$ \\
\hline Perlakuan & 367867,4 & 3 & 122622 & $18,32^{*}$ & $2,13 \mathrm{E}-06$ & 3,01 \\
Galat & 160681,9 & 24 & 6695 & & & \\
Total & 528549,4 & 27 & & & & \\
\hline
\end{tabular}

Tabel 8. Hasil uji Anova luas kanopi daun pada taraf 5\%

\begin{tabular}{cc}
\hline Perlakuan & Rata-rata \\
\hline P0 & $52,62^{\mathrm{a}}$ \\
P1 & $120,00^{\mathrm{a}}$ \\
P2 & $181,98^{\mathrm{b}}$ \\
P3 & $360,91^{\mathrm{b}}$ \\
\hline
\end{tabular}

\section{Total brangkasan}

Berat total segar (total brangkasan) tanaman sawi dapat dilihat pada Gambar 4. Berdasarkan grafik, rata-rata total brangkasan pada P1 lebih besar dari P0, P2 lebih besar dari P1 dan P3 lebih besar dari P2. Pengaruh perlakuan terhadap total brangkasan tidak hanya dapat dilihat dari grafik tetapi dilihat berdasarkan hasil uji anova dan uji BNT pada Tabel 9 dan 10.

Hasil uji anova menyatakan bahwa perlakuan yang diberikan berpengaruh nyata terhadap berat total brangkasan. Hasil uji BNT menunjukkan bahwa pemberian pupuk organik berbasis mikroba (P1), biochar arang sekam (P2) dan kombinasi keduanya (P3) berpengaruh meningkatkan total brangkasan dibanding kontrol (P0). Pengaruh pemberian pupuk saja (P1) atau biochar saja (P2), tidak berbeda nyata pada taraf uji $5 \%$. Kombinasi pupuk organik berbasis mikroba dan biochar (P3) memberikan pengaruh yang lebih baik dibandingkan pemberian biochar sekam padi saja (P2) atau pupuk organik berbasis mikroba saja (P1).

Hasil pengujian ini menunjukkan bahwa kombinasi biochar arang sekam dan pupuk organik berbasis mikroba efektif meningkatkan pertumbuhan tanaman sawi karena tanaman sawi yang dipanen adalah total brangkasan segarnya 


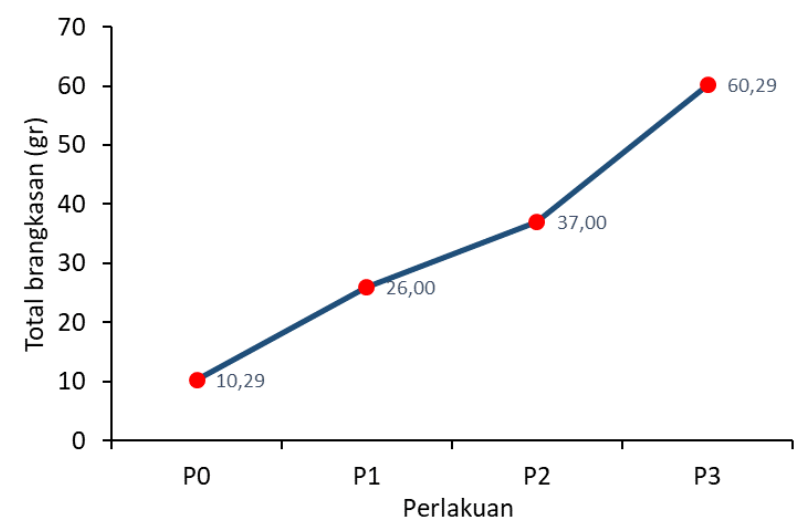

Gambar 4. Pengaruh perlakuan terhadap total brangkasan

Hasil penelitian ini sesuai dengan hasil penelitian (Wibowo et al., 2017) yang menyatakan bahwa perpaduan aplikasi biofertilizer berbasis biochar memberikan pengaruh signifikan terhadap berat kering dan yield tanaman sawi.

Tabel 9. Hasil uji anova total brangkasan pada taraf uji 5\%

\begin{tabular}{ccccccc}
\hline $\begin{array}{c}\text { Source of } \\
\text { Variation }\end{array}$ & \multicolumn{1}{c}{ SS } & $d f$ & MS & $F$ & $\begin{array}{c}P \text { - } \\
\text { value }\end{array}$ & F crit \\
\hline Perlakuan & 9273,82 & 3 & 3091,27 & $19,84^{*}$ & $10-6$ & 3,02 \\
Galat & 3738,86 & 24 & 155,78 & & & \\
Total & 13012,68 & 27 & & & & \\
\hline
\end{tabular}

Tabel 10. Hasil uji BNT total brangkasan pada taraf uji 5\%

\begin{tabular}{cc}
\hline Perlakuan & Rata-rata \\
\hline P0 & $10,29^{\mathrm{a}}$ \\
P1 & $26,00^{\mathrm{b}}$ \\
P2 & $37,00^{\mathrm{b}}$ \\
P3 & $60,29^{\mathrm{c}}$ \\
\hline
\end{tabular}

\section{KESIMPULAN}

Pemberian pupuk organik berbasis mikroba pada tanah subsoil yang digunakan untuk budidaya tanaman sawi berpengaruh terhadap tinggi tanaman, jumlah daun dan total brangkasan tetapi tidak berpengaruh terhadap luas kanopi daun.

Pemberian biochar arang sekam pada tanah subsoil yang digunakan untuk budidaya tanaman sawi berpengaruh terhadap tinggi tanaman, jumlah daun, luas kanopi daun, dan total brangkasan

Kombinasi pupuk organik berbasis mikroba dan biochar arang sekam pada tanah subsoil yang digunakan untuk budidaya tanaman sawi berpengaruh terhadap tinggi tanaman, dan total brangkasan.

Kombinasi pupuk organik berbasis mikroba dan biochar arang sekam tidak memberikan pengaruh yang signifikan terhadap jumlah daun dan luas kanopi jika dibandingkan dengan pemberian biochar arang sekam saja.

\section{DAFTAR PUSTAKA}

Baidoo, I., Sarpong, D. B., \& Bolwig, S. (2016). Biochar amended soils and crop productivity: A critical and meta-analysis of literature. International Journal of Development and Sustainability, 5(9), 414-432.

Ding, Y., Liu, Y., Liu, S., Li, Z., Tan, X., Huang, X., Zeng, G., Zhou, L., \& Zheng, B. (2016). Biochar to improve soil fertility. A review. Agronomy for Sustainable Development, 36(2), 36. https://doi.org/10.1007/s13593-016-0372-z

Elviwirda. (n.d.). Peranan Biochar Dalam Meningkatkan Kesuburan Tanah. Retrieved February 12, 2020, from http://nad.litbang.pertanian.go.id/ind/index.php/info -teknologi/1092-peranan-biochar-dalammeningkatkan-kesuburan-tanah

Gani, \& Anischan. (2009). Potensi Arang Hayati Biochar sebagai Komponen Teknologi Perbaikan Produktivitas Lahan Pertanian-PDF Free Download. Adoc. Pub, 4(1), 33-48.

Gonzaga, M. I. S., Mackowiak, C. L., Comerford, N. B., Moline, E. F. da V., Shirley, J. P., \& Guimaraes, D. V. (2017). Pyrolysis methods impact biosolidsderived biochar composition, maize growth and nutrition. Soil \&amp; Tillage Research, 165, 59-65.

Handoko, A. P., Wicaksono, K. S., \& Rayes, M. L. (2017). Pengaruh Kombinasi Arang Tempurung Kelapa dan Abu Sekam Padi terhadap Perbaikan Sifat Kimia Tanah Sawah serta Pertumbuhan Tanaman Jagung. (JTSL) Jurnal Tanah Dan Sumberdaya Lahan, 3(2), 381-388.

Kumarathilaka, P., Mayakaduwa, S., Herath, I., \& Vithanage, M. (2016). Biochar: State of the Art. In Biochar Production, Characterization, and Applications (pp. 17-42). CRC Press.

Lehmann, J., \& Joseph, S. (Eds.). (2009). Biochar for Environmental Management: Science and Technology (1 edition). Earthscan Publications Ltd.

Nisa, K. (2010). Pengaruh Pemupukan NPK Dan Biochar Terhadap Sifat Kimia tanah, serapan Hara, Dan Hasil Tanaman Padi sawah [Universita Syah Kuala]. https://scholar.google.com/citations?view_op=view _citation\&hl=en\&user=dBysMgsAAAAJ\&citation_fo $\bar{r}$ _view=dBysMgsAAAAJ:8k81kl-MbHgC

Nurida, N. L., Rachman, A., \& Sutono, S. (2015). BIOCHAR, PEMBENAH TANAH YANG POTENSIAL. IAARD Press. http://balittanah.litbang.pertanian.go.id/ind/dokume ntasi/lainnya/Buku\%20Biochar.pdf

Rajaphaksa, A. U., Mohan, D., Igalavithana, A. D., Lee, S. S., \& Ok, Y. S. (2016). Definitions and Fundamentals of Biochar. In Biochar Production, Characterization, and Applications. CRC Press.

Rondon, M. A., Lehmann, J., Ramírez, J., \& Hurtado, M. (2007). Biological nitrogen fixation by common beans (Phaseolus vulgaris L.) increases with biochar additions. Biology and Fertility of Soils, 43(6), 699-708.

Sandhu, S. S., Ussiri, D. A. N., Kumar, S., Chintala, R., Papiernik, S. K., Malo, D. D., \& Schumacher, T. E. (2017). Analyzing the impacts of three types of biochar on soil carbon fractions and physiochemical properties in a corn-soybean rotation. Chemosphere, 184, 473-481. https://doi.org/10.1016/j.chemosphere.2017.05.16 5

Simanungkalit, R. D. M., Suriadikarta, D. A., Saraswati, R., Setyorini, D., \& Hartatik, W. (2006). Pupuk organik dan pupuk hayati (Vol. 312).

Topani, K., Siswanto, B., \& Suntari, R. (2017). Pengaruh Aplikasi Bahan Organik Pembenah Tanah terhadap Sifat Kimia Tanah, Pertumbuhan dan 
Produksi Tanaman Tebu di Kebun Percobaan Pabrik Gula Bone, Kabupaten Bone. (JTSL) Jurnal Tanah Dan Sumberdaya Lahan, 2(1), 155-162.

Wibowo, S. A., Wiguna, E. C., Susilo, B., Dalimartha, L. N., \& Prasetiyo, E. N. (2017). Pengaruh Biochar Berbasis Biofertilizer untuk Meningkatkan Produksi Sawi (Brassica juncea L.). Proceeding Biology Education Conference: Biology, Science, Enviromental, and Learning, 14(1), 271-275.

Widyantika, S. D., \& Prijono, S. (2019). Pengaruh Biochar Sekam Padi Dosis Tinggi terhadap Sifat Fisik Tanah dan Pertumbuhan Tanaman Jagung pada Typic Kanhapludult. (JTSL) Jurnal Tanah Dan Sumberdaya Lahan, 6(1), 1157-1163. https://doi.org/10.21776/ub.jtsl.2019.006.1.14 